\title{
ЛИНГВОСЕМИОТИЧЕСКИЕ ОСОБЕННОСТИ ЗНАКОВ СМЕРТИ В РУССКИХ НАРОДНЫХ СКАЗКАХ
}

В статье проанализированы и систематизировань смешанные знаки смерти, представленные в 250 русских народных сказках, собранных А. Н. Афанасьевым (индекс + икона; индекс + символ; символ + индекс; символ + индекс + икона). Систематизация знаков проводилась в соответствии с классификацией, предложенной 4. С. Пирсом

Исследование знаков смерти позволяет охарактеризовать древнейшие фундаментальные представления русского человека о мироустройстве, выявить источники представлений о смерти, закрепленных в русской языковой картине мира, и проанализировать отношение к смерти как к одному из основных бытийных феноменов. Несмотря на тщательное описание констант русской языковой картины мира, наличие нескольких монографий о ее составляющих, феномену смерти, определяющему развитие духовно-нравственной культуры народа, в отечественном языкознании не уделяется достаточного внимания. Данный факт определяет актуальность настоящего исследования. В статье предпринимается попытка охарактеризовать смыслы и значения знака смерть в народных сказках, собранных А. Н. Афанасьевым. Богатый фольклорный материал позволил автору описать развитие представлений о смерти. Применяемый в исследовании лингвосемиотический подход дает возможность изучить структуру знаков смерти, их источники (мифологические, научные, религиозные, бытовые), частотность обращения к тому или иному знаку в тексте сказок.

Научная новизна работы обоснована самой постановкой проблемы: впервые в отечественном языкознании проводится анализ знаков смерти на базе фольклорного материала, дается лингвосемиотическая классификация данных знаков. Результаты исследования могут быть применены при дальнейшем изучении феномена смерти в лингвистике, лингвокультурологии, лингвосемиотике (или изучении жизни как тесно связанного со смертью феномена).

Ключевые слова: лингвосемиотика, знак, смешанные знаки, языковая картина мира, ключевое слово, феномен смерти.

\section{A. Pisarenko}

\section{LINGUOSEMIOTIC PECULIARITIES OF DEATH SIGNS IN RUSSIAN FOLK TALES}

The article analyzes and systematizes the mixed signs of death, presented in 250 Russian folk tales collected by A. N. Afanasyev (index + icon; index + symbol; symbol + index; symbol + index + icon). The systematization of signs was carryied out in accordance with the classification proposed by C. S. Pierce.

The study of the signs of death allows us to characterize the ancient fundamental ideas of Russians about the world order, identify the sources of ideas about death, enshrined in the Russian language picture of the world, and analyze the attitude to death as one of the main phenomena. Despite the careful description of the constants of the Russian language picture of the world, the presence of several monographs about its components, the phenomenon of death, which determines the development of the spiritual and moral culture of the people, is not given sufficient attention in domestic linguistics. This fact determines the relevance of this study. The article attempts to characterize the mean- ing of the sign of death in folk tales collected by A. N. Afanasyev. Rich folk material allowed the author to describe the development of ideas about death. The linguosemiotic approach used in the study makes it possible to study the structure of the signs of death, their sources (mythological, scientific, religious, everyday), the frequency of references to a particular sign in the text of fairy tales.

The scientific novelty of the work is justified by the formulation of the problem: for the first time in the domestic linguistics, an analysis of the signs of death is carried out based on a folk material; a linguo-semiotic classification of these signs has given. The results of the study can be applied to further study the phenomenon of death in linguistics, linguistic culturology, linguosemiotics (or the study of life as a phenomenon closely related to the death).

Key words: linguosemiotics, sign, mixed signs, linguistic picture of the world, keyword, the phenomenon of death.

зыковой рефлексии, с помощью анализа так называемых ключевых слов, или ключевых идей, «культурно значимых слов-концептов» [5], называющих определяющие данную культуру явления. Смерть относится к числу базовых, инвари- 
антных для многих языковых культур бытийных феноменов; изучение феномена смерти в русском языке позволяет охарактеризовать основы духовно-нравственной культуры русского народа, ценностные ориентиры, главенствующие в обществе в настоящее время.

Особенности мировосприятия русского народа, представления о ключевых для русской языковой картины мира идеях в полном объеме можно изучить на фольклорном материале, а именно на основе текстов народных сказок.

Материалом для статьи послужили 250 русских народных сказок, собранных А. Н. Асранасьевым. В результате лингвосемиотического анализа в сказках были выявлены знаки смерти, разделенные на группы в соответствии с базовой классификацией знаков американского ученого-семиотика Ч. С. Пирса. Он выделил три основных вида знаков: «Во-первых, подобия (likenesses), или иконы (icons), которые выполняют фуункцию передачи идей и репрезентируют вещи, просто имитируя их. Во-вторых, существуют указатели (indications), или индексы (indices), которые что-то говорят о вещах, потому что физически связаны с ними... В-третьих, существуют симво- лы, или общие знаки, которые ассоциируются с их значениями (meanings) благодаря привычке» [10]. К наиболее совершенным Ч. С. Пирс относил смешанные знаки, которые включают два или три вида знаков; именно знаки смешанной природы репрезентируют языковую картину мира человека: «Во всех рассуждениях мы употребляем смесь подобий, индексов и символов. Мы не можем обойтись без каждого из этих видов. Весь комплекс целиком может быть также назван символом, поскольку в рассуждении превалирует символический, живой характер» [10].

В изучаемых сказках представлены исключительно смешанные знаки, совмещающие два или более типов (знак, находящийся на первом месте, преобладает):

- индекс + икона;

- индекс + символ;

- символ + индекс

- символ + индекс + икона

К смешанному знаку индекс + икона относятся такие знаки, которые совмещают прямое указание на смерть и изображение смерти или ее признаков (табл. 1).

Таблица 1

Знак индекс + икона

Знак Название сказки

Кости (или другие части тела мертвого человека - «Лиса-лекарка», «Кот, петух и лиса» (№ 37), «Мизгирь» (№ 6), головы, черепа) «Морской царь и Василиса Премудрая», «Морозко» (№ 96), «Дочь и падчерица», «Кобиляча голова», «Баба Яга» (№ 102 № 103, № 104), «Иван Быкович» «Марья Моревна», «Чудесная курица», «Сказка о молодце-удальце, молодильных яблоках и живой воде» (№ 175), «Безногий и слепой богатыри» (№ 198) «Морской царь и Василиса Премудрая) (№ 222, № 224 , № 225), «Бесстрашный» (№ 350)

Покойник, мертвое тело

«Морозко» (№ 96), «Сказка о молодце-удальце, молодильных яблоках и живой воде» (№ 171, № 176), “Сивко-бурко» (№ 179) «Свинка золотая щетинка, утка золотые перышки, золоторогий олень и золотогривый конь» (№ 182, № 184), «Звериное молоко» (№ 203), «Бесстрашный» (№ 348-350), «Рассказы о мертвецах》 (№ 351-362)

Неподвижность (часто сочетается с другими видимыми и воспринимаемыми органами чувств признаками смерти - неприятный запах, предсмертная гримаса, окостенение тела, молчание)

«Лисичка-сестричка и волк» (№ 1, № 4, № 7), «Лиса-повитуха» (№ 10, № 11), «Смерть петушка», «Мизгирь» (№ 85, № 86), «Бесстрашный) (№ 350), «Рассказы о мертвецах» (№ 351, № 355, № 356)

Спящий человек

«Иван-царевич и Белый Полянин», «Сказка об Иване-царевиче, жар-птице и о сером волке», «Сказка о молодце-удальце», «Чудесная курица», «Мертвое тело» (№ 396)

Исходя из данных таблицы, мы можем сделать вывод, что к одному из самых распространенных знаков типа индекс + икона относятся кости. Кости в русской языковой картине мира означают основу человеческого тела, его материального состава. Кости связаны со смертью причинно-следственными отношениями, то есть по смежности, индексально (скелет - то, что остается от человека после его кончины); также кости являются прямым изображением смерти персонажа, то есть соединяются с ней иконически. От умерших сказочных героев зачастую остаются только косточки: "Старик спустился вниз по кочешку, поднял мешок, а в мешке одно костье, и то примельчалось» [1, с. 26]; «с вечеру пойдет богатырь во дворец и здоровый и сильный, а к утру одни косточки останутся» [1, с.799]. Человеческие кости и черепа могут выступать как предостережение об опасности или о подстерегающей героев смерти: «Приезжают к реке Смородине; по всему берегу лежат кости человеческие, по колено будет навалено!» $[1$, с.219] 
Кости - знак с амбивалентной семантикой. Несмотря на то, что они прямо указывают на смерть сказочного персонажа, кости также неразрывно связаны с жизнью, в них хранится память о человеке, его душа. Согласно древним славянским воззрениям, кости умершего нельзя беспокоить. С этим связано представление о «нечистой» смерти в народных сказках - разьединение костей "Они на то не согласилися, убили еао и косточки разбросали по чистому полю» [1, с. 349] «Волшебный конь разнесёт его кудри по ветру размычет его кости по чисту полю» [1, с. 421].

Сказочный мотив прорастания из костей волшебного дерева, ракитового куста (в этом случае кости - индексальный знак жизни; иногда функцию костей выполняет гузенная кишочка (конец толстой кишки) или пепел животного) соотносится с редким вятским обрядом троецыплятницы [6] в ходе которого участники (исключительно женщины) после обрядового обеда хоронили или пускали по реке куриные кости.

Распространенными являются также знаки покойник, мертвое тело. Два этих знака, отнесенных нами к одной группе, по своей семантике различаются. Мертвое тело - видимый, эмпирически познаваемый знак смерти, связанный с ней по смежности и прямо изображающий ее. Мертвое тело свидетельствует об окончательной кончине человека; оно может быть холодным, неподвижным: «старуха выбежала встретить дочь, да вместо ее обняла холодное тело» [1, с. 112]. Покойник или мертвец, появляющиеся в сказке, как правило, ночью начинают вести себя как живые двигаются, разговаривают. С рассветом, с пением петухов данные способности утрачиваются. Появляются мертвецы в местах, символизирующих границу «верха» и «низа», «этого» и «того» света, - на дереве, на могиле, на распутье: «Едуm дорогою, алядь - в стороне дерево, на дереве покойник висит, за ноги привязан» [1, с. 798]; «Вот могила растворилась, и оттуда вышел мертвец с аробовою крышкою, в белом саване» [1, с. 802]; «в неуказные часы идет мимо кладбища и видum: cmoum на распутии мертвец в белом саване» [1, с. 807-808]. По народным представлениям, «оживать» покойники могли в том случае, если с их телами не были проведены ритуалы, обеспечивающие защиту от смерти живым и благополучный переход на «тот свет» мертвым. Еще один способ оградить живых от смерти - нарушить целостность мертвого тела; этот мотив часто встречается и в русских народных сказках: ‘...убрал своих покойников, а наутро вырыл на дворе больиую яму, положил их туда лицом книзу, заколотил каждому по осиновому колу в спину и закидал землею: с тех пор полно вставать по ночам да царапаться!» [1, с. 800]; "собрался народ и повалил на кладбище, отыскали могилу, из которой мертвец выходил, разрыли и вбили ему прямо в сердие осиновый кол, чтоб больше не вставал да людей не морил» [1, с. 803]

К внешним - видимым, ощущаемым, осязаемым - признакам кончины относятся неподвижность и неподвижность в сочетании с другими телесными проявлениями смерти (неприятный запах, смертная гримаса, окостенение, молчание). Знаки связаны с рефрерентом - смертью причинно-следственными отношениями (например, запах - следствие разложения тела после кончины), а также прямо изображают его. Зачастую сказочные персонажи используют свои знания о смерти, чтобы притворяться мертвыми: "Кума рассердилась, пошла куды-то и леела на дорогу, а мужик с рыбой ехал, да и думает, что лисичка пропала, взял ее и бросил на сани» $[1$, c. 17]; «Выбежала на дорогу, видит - едет с сельдями мужик, прикинулась и легла поперек дороги, как умерла» [1, с. 18]. Мертвецы, оживающие в полночь, с появлением первых солнечных лучей перестают двигаться и замолкают: «мертвец ничего не говорит, молчит - знать, время не пришло еще ему говорить-то» [1, с. 802]; "старик окостенел и замолчал» [1, с. 806]. Окостеневшие покойники в сказочном тексте сравниваются с неподвижными твердыми предметами: «а мертвецы на каком месте стояли, на том и повалились, словно колоды» [1, с. 800]; «ту самую минуту колдун омертвел: лежит, не тронется, словно деревянная колода» [1, с. 807].

Сонный человек уподобляется мертвому. Запрещено убивать спящего; такая смерть считается «злой», недостойной: «сонный человек - что мертвый» [1, с. 331] (данная фрормула повторяется в сказках «Иван-царевич и Белый Полянин», «Сказка об Иване-царевиче, жар-птице и о сером волке», “Сказка о молодце-удальце»). Смерть вечный сон: "..поднял дубинку да как треснет старуху по голове - так она и не ворохнулась, навеки уснула!» [1, с. 858]. Знак также связан со смертью по смежности (сон - переходное состояние, близкое к смерти; спящий человек находится на границе двух миров) и иконически (спящий или сонный внешне подобен мертвому).

Знаки, относящиеся к группе индекс + символ, указывают на денотат как прямо, так и условно, на основе соглашения (табл. 2).

Таблица 2

Знак индекс + символ

\begin{tabular}{|l|l|}
\hline \multicolumn{1}{|c|}{ Знак } & \multicolumn{1}{|c|}{ Название сказки } \\
\hline Кровь & $\begin{array}{l}\text { «Иван Попялов», «Буря-богатырь Иван коровий сын», «Иван Быкович», «Иван крестьянский сын } \\
\text { и мужичок сам с пёрст, усы на семь верст», «Два Ивана солдатских сына», «Кощей Бессмертный» } \\
\text { (№ 156), «Чудесная рубашка» }\end{array}$ \\
\hline Серебро & «Марья Моревна» \\
\hline Свеча & «Буря-богатырь Иван коровий сын» \\
\hline Саван & «Рассказы о мертвецах» (№ 351 - 352, № 356-357) \\
\hline
\end{tabular}


Знаки кровь, серебро и свеча по значению соотносятся между собой: в славянской картине мира они символизируют жизнь, свет, силу и здоровье человека, но в то же время при определенных условиях могут приобрести прямо противоположный смысл - стать символом смерти, тьмы и болезни. В сказках эти предметы изменяются, портятся: кровь льется из вещи, принадлежащей герою (рукавица, платок, полотенце), или темнеет; серебро чернеет; свеча тухнет. По мнению В. Я. Проппа, в предметах заключена часть души персонажа [11]; именно поэтому их должны охранять кровные родственники (как правило, братья). Изменившийся предмет указывает на уже свершившуюся или подстерегающую персонажа смерть: «Иван павесив сваи рукавицы да ка́жа брата́м: «Як из маих рукавиц патяче́ кровь, дак прибеаáŭme ка мне на по́мачь» [1, с. 207]; «поставил стол и свечку, воткнул в стену ножик, повесил на него полотенце, дал братьям колоду карт и говорит: "Играйте, ребята, в карты, да меня не забывайте; как станет свеча догорать, а с этого полотенца будет в тарелке кровь прибывать, то беаите скорей на́ мост, ко мне на подмогу» [1, с. 212]; "В то самое время у зятьев Иван-царевича серебро почернело. "Ах, - говорят они, - видно, беда приключилася!» [1, с. 298]. Дуализм, двойственная семантика знаков, символизирующих одновременно жизнь и смерть, здоровье и болезнь, свет и тьму, является отражением аксиологической поляризации, свойственной для русского языка и русской картины мира вообще.

Еще один повторяющийся в сказках и связанный с кровью мотив - убийство превращенных в разные предметы змеевых сестер или жен. Согласно принципу тройственности, лежащему в основе сказки, три женщины поочередно превращаются в заманчивые для героев предметы например, яблоню, колодец и кровать («Иван Быкович»), подушки, яблоню, крыницу («Иван Попялов»). Из разрубленных предметов течет кровь, указывая на смерть помощниц антагониста.

Свеча связана со смертью также через содержание погребальных и похоронных обрядов. Она освещает умершему человеку путь на «тот свет». «Не зажечь свечу для умирающего и не принести свечу для прощания с покойным считается великим грехом» [3]. Из серебра изготавливали ритуальные предметы.

Таким образом, кровь, серебро и свеча одновременно указывают на смерть (изменение этих предметов означает кончину героя) и символизируют ее, связываясь с ней условно, на основании соглашения.

Саван указывает на переходное состояние человека, находящегося на границе двух миров. В сказках саван обычно белого цвета; он помогает отличить живого человека от ожившего мертвеца. Покойники в саване появляются в местах, индексально или символически связанных со смертью, на могиле, на распутье, в опасное время суток в полночь: "...мертвец в белом саване сидит на могиле» [1, с. 802]; "стоит на распутии мертвец в белом саване» [1, с. 808]; "Ровно в деенадцать часов попадали все запоры и растворились все двери; входит в избу покойник в белом саване...» $[1$, с. 807$]$

Также можно выделить тип знака, совмещающий прямое указание на денотат и условную связь с ним, но в другом соотношении, - символ + индекс (табл. 3). Символ здесь превалирует над индексом, является доминирующим, главенствующим.

Таблица 3

Знак символ + индекс

\begin{tabular}{|l|l|}
\hline \multicolumn{1}{|c|}{ 3нак } & \multicolumn{1}{|c|}{ Название сказки } \\
\hline «Тот свет» & «Старик лезет на небо», «Старик на небе», «Ведьма и Солнцева сестра», «Князь Дани- \\
& ла-говорила», «Три царства - медное, серебряное и золотое» (№ 128-130), «Норка-зверь», \\
& «ван Сученко и Белый Полянин», «Зорька, Вечорка и Полуночка», «Медведко, Усыня, \\
& Горыня и Дубыня-богатыри», «Летучий корабль», «Батрак», «Шабарша», «Иванко Медвед- \\
& ко», «Иван-царевич и Белый Полянин», «Сказка о молодце-удальце, молодильных яблоках \\
& и живой воде» (№ 171, № 173, № 176), «Петухи жерновки», «Чудесный ящик», «Волшебное \\
& кольцо» (№ 191), «Поди туда - не знаю куда, принеси то - не знаю что» (№ 214), «Мудрая \\
& жена», «Морской царь и Василиса Премудрая» (№ 226) \\
\hline
\end{tabular}

"Тот свет" - одно из центральных понятий славянской мифологии, «связанных с верой в посмертное существование души и культом предков» [4], это место, по предположению человека, символизирует смерть. Появление на «том свете» - доказательство реальной или символической смерти персонажа, то есть «тот свет» не только символизирует кончину, но и указывает на нее. Герой волшебных сказок, попадая на «тот свет», пересекает границу двух миров, после чего начинает проходить различные испытания. Расположение «того света» связано с религиоз- ными христианскими представлениями славян о рае и аде. Чаще всего в сказках «тот свет» находится внизу - под землей или под водой. Герой спускается туда либо по канату, веревке, ремню, либо отворотив камень или пень; попадает в мир смерти через расступившееся море: «вынул из кармана три больиих ремня, что вырезал у бабы-яаи, привязал их к веревке и опустился на mот свет» [1, с. 241]; «зверь дабеа да великага белага камня, падняв яго и пашов на той свет» [1, с. 193]; «Вот клубочек катился-катился - и прямо в море: море расступилося, дорога от- 
крылася; дурак ступил раз-другой и очутился с своими провожатыми на том свете» [1, с. 494] Не всегда персонаж сказки оказывается на «том свете» по своей воле: его бросают в пропасть ревнующие братья («Сказка о молодце-удальце молодильных яблоках и живой воде»), или земля расступается под его ногами («Князь Данила-говорила»). Значительно реже "тот свет» расположен наверху: герой попадает туда, встав на весы с ведьмой («Ведьма и Солнцева сестра»), взобравшись по выросшему до небес растению ( СТарик лезет на небо», “Старик на небе», «Петух и жерновки»).

Рассматриваемый знак в фольклоре неоднозначен и противоречив. Если “тот свет» расположен наверху, то там могут находиться полезные для человека волшебные предметы (например, в сказке «Петух и жерновки» старик приносит с небес волшебные жерновцы). Под землей же человека ждет нечисть - черти, ведьмы. Черти обитают рядом с водой или на мельнице. Мельница - демонический объект. «Полагали, что при строительстве мельницы мельник делает заклад иногда в фоорме завета - это жертвоприношение нечистой силе» [12].
В сказке «Три царства - медное, серебряное и золотое» соотнесенность "того света» с сакральным миром подчеркивается с помощью названий царств. Медь, серебро и золото в народном сознании конвенционально связаны с божественным началом, светом, красотой. В царствах героя встречает не враг-антагонист, а три прекрасные девицы-колпицы. Птицы в мифологической символике противопоставлены подземным гадам и тварям («низу»), символизируют человеческую душу: таким образом, в сказке девушки, путь к царству которых лежит через «яму подземельную», условно относятся к «верху», выделяются из своего окружения. С образом смерти в сказке соотносится Ворон Воронович: ворон, в отличие от колпиц, принадлежит к «нечистым» хтоническим птицам (создание которых приписывается черту) и связан с миром мертвых. Изображение той или иной птицы также означает «верх» и «низ», то есть колпицы и ворон одновременно являются символом и иконой.

Все три типа знака - символ, индекс и икону - совмещают герои - персонификации смерти (табл. 4).

Знак символ + индекс + икона

Таблица 4

\begin{tabular}{|c|c|}
\hline Знак & Название сказки \\
\hline Баба-яга & 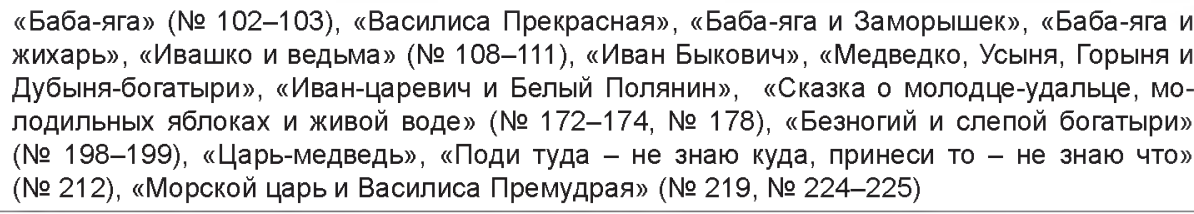 \\
\hline Кощеей Бессмертный & «Кощей Бессмертный» (№ 156 - 158), «Марья Моревна» \\
\hline Смерть & «Бесстрашный» (№ 349) \\
\hline
\end{tabular}

Образы Бабы-яги и Кощея Бессмертного семантически многоплановы. В настоящее время в фольклористике нет единого мнения о происхождении и структуре этих знаков. Они одновременно зооморфны и антропоморфны, принадлежат к миру мертвых и миру живых. Однако несмотря на формальную схожесть функций, сказочные герои отличаются по нескольким показателям.

Баба-яга - женский демон [14] (Н. А. Терновская, Н. И. Толстой), «лесная старуха-волшебница» [7] (В. В. Иванов, В. Н. Топоров), богиня смерти [8] (К. Д. Лаушкин), “олицетворение зимних бурь» [2]. Не всегда Яга - отрицательный персонаж, она может и помогать герою советом, дать ему волшебный предмет («Поди туда - не знаю куда, принеси то - не знаю что» (№212) "Морской царь и Василиса Премудрая» (№ 219 №224-225).

Яга связана со смертью прежде всего через обряд инициации; она охраняет "тот свет», мир мертвых, от мира живых.

Для воссоздания внешнего вида Бабы-яги необходимо обращаться не к одной, а сразу к нескольким сказкам. Яга - старуха с костяной (или золотой) ногой, ощущающая запах живого человека как нечто чужеродное. К. Д. Лаушкин рассматривает костеногость героини как оставшуюся от ее зооморфного, змеиного облика черту [8]. Баба-яга также икона, изображение олицетворенной, персонифицированной Смерти: «это старуха, худая и страшная (с.-рус.), ... она беззубая или зубастая (чеш. lazubala), с большими руками, которыми она может везде дотянуться, с длинными ногтяи-когями (макед.), с большим ртом (словац.), хромая - одна нога короче другой (чеш.)» [15]. У Яги, как и у смерти, есть атрибуты. Смерть пользуется сельскохозяйственными орудиями (косой, тяпкой), чтобы забрать человека в мир мертвых; сказочная героиня использует домашнюю утварь для передвижения. Она разьезжает на ступе, погоняя пестом или железным толкачом: «Скоро послышался в лесу страшный иум: деревья трещали, сухие листья хрустели; выехала из лесу баба-яга - в ступе едет, пестом погоняет, помелом след заметает» [1, с. 125].

Образ Яги, представление о ней дополняет описание ее жилища, изображенного как изба пожирательницы людей, людоедки. Оно пре- 
достерегает героя, указывая на то, что там его поджидает сама Смерть: «забор вокруе избы из человечьих костей, на заборе торчат черепа людские, с глазами; вместо верей у ворот ноги человечьи, вместо запоров - руки, вместо замка́ - рот с острыми зубами» [1, с. 124].

Интерпретации образа Кощея во многом схожи с пониманием образа Бабы-яги. Кощей владыка «того света» [13] (Ю. С. Степанов), бог Зимы-Смерти [16] (Дж. Кертин), олицетворение Смерти [9] (Т. А. Новичкова).

Если облик Бабы-яги можно воссоздать на основе нескольких сказок, то внешность Кощея в фольклорных текстах не описывается вовсе. На принадлежность Кощея Бессмертного к миру мертвых указывает то, что он так же, как Яга, не переносит запах живого человека. Некоторые свойства, способности героя позволяют отнести его к зооморфным существам. Кощей, подобно сказочному Змею или птице, умеет летать: «Только что гости успели спрятаться, прилетает с охоты Кощей Бессмертный» [1, с. 292].

Смерть Кощея оторвана от него, спрятана она обычно в яйце. Яйцо -значимый символ, связанный с космогоническими мифами, с представлениями о мироустройстве. Уничтожение яйца влечет за собой смерть героя.
Функции Бабы-яги и Кощея могут выполнять другие герои: Змей, Ветер, ведьма Чувилиха. В сказках «Федор Тугарин и Анастасия Прекрасная», «Хрустальная гора» смерть Змея, как и смерть Кощея, таится вне его тела: в камешке, в семечке. Ведьма Чувилиха из сказки «Терешечка» является аналогом Яги-людоедки; живет она в избушке на курьих ножках.

В одной из проанализированных сказок («Бесстрашный», №349) Смерть появляется в виде мертвеца. Она приходит по ночам и пожирает детей: «В самую полночь пришел мертвец. Барин спрашивает его: "Кто пришел?» - «Смерть!» $[1$, c. 797$]$.

Таким образом, в сказках представлено четыре типа смешанных знаков смерти. Знаки, относящиеся к группе индекс + икона, связаны со знаниями человека о биологической кончине, представляют собой внешние признаки смерти. Знаки, объединяющие индекс и символ, сопряжены со смертью через похоронную и погребальную обрядовость. Группа символ + индекс представлена одним знаком («тот свет»), отражающим религиозные воззрения человека. Самые древние и неоднозначные в семантическом отношении знаки входят в группу символ + индекс + икона.

\section{Литература}

1. Афанасьев А. Н. Народные русские сказки. Полное издание в одном томе. М.: Издательство АЛЬФА-КНИГА, 2017. $1087 \mathrm{c}$

2. Баба-яга // Энциклопедический словарь Брокгауза и Ефрона: в 86 т. (82 т. и 4 доп.). СПб. [б.и.], 1890-1907. С.5.

3. Белова О. В., Седакова И. А. Свеча // Славянские древности: Этнолингвистический словарь в 5-ти томах. Т.4. М.: Международные отношения, 2009. C.567-573.

4. Виноградова Л. Н., Толстая С. М. «Тот свет» // Славянские древности: Этнолингвистический словарь в 5-ти томах. Т.5. М.: Международные отношения, 2012. С. 298-303.

5. Зализняк А. А., Левонтина И. Б., Шмелев А. Д. Константы и переменные русской языковой картины мира. М.: Языки славянских культур, 2012. 696 с.

6. Зеленин Д. К. Избранные труды. Статьи по духовной культуре 1901-1913. М.: Индрик, 1994. С.105-150.

7. Иванов В. В., Топоров В. Н. Баба Яга // Славянская мифология: энциклопедический словарь. 2-е изд. М.: Международные отношения, 2002. $512 \mathrm{c}$.

8. Лаушкин К. Д. Баба-Яга и одноногие боги (К вопросу о происхождении образа) // Фольклор и этнография. Ленинград: Наука, 1970. С. 181-186.

9. Новичкова Т. А. Русский демонологический словарь. СПб.: Петербургский писатель, 1995. 640 с.

10. Пирс Ч. С. Что такое знак? // Вестник Томского государственного университета. Философия. Социология. Политология. Томск: ТГУ, 2009. С. 88-95

11. Пропп В. Я. Исторические корни волшебной сказки. М.: Лабиринт, 2000.274 с

12. Седакова И. А. Мельница // Славянские древности: Этнолингвистический словарь в 5-ти томах. Т.3. М.: Международные отношения, 2004. С. 222-225.

13. Степанов Ю. С. Константы: Словарь русской культуры. М.: Языки русской культуры, 2004. 824 с

14. Терновская Н. А., Толстой Н. И. Баба // Славянские древности: Этнолингвистический словарь в 5-ти томах. Т. 1. М.: Международные отношения, 1995. С. 122-123.

15. Толстая С. М. Смерть // Славянские древности: Этнолингвистический словарь в 5-ти томах. Т. 5. М.: Международные отношения, 2012. С. 58-71

16. Curtin I. Myths and Folk-Tales op the Russians, Western Slavs and Magyars. London, 1890. 551 p.

\section{References}

1. Afanas'ev A. N. Narodnye russkie skazki . Polnoe izdanie v odnom tome (Folk Russian Fairy Tales. Complete Edition in One Volume). Moscow: «Izdatel'stvo AL"FA-KNIGA», 2017. 1087 p. (In Russian).

2. Baba-yaga // Entsiklopedicheskii slovar' Brokgauza i Efrona: v 86 t. (82 t. i 4 dop.). St.Petersburg, 1890-1907. P. 591 (In Russian).

3. Belova O. V., Sedakova I. A. Svecha (Candle) // Slavyanskie drevnosti: Etnolingvisticheskii slovar' v 5-ti tomakh. Vol. 4. Moscow.: Mezhdunarodnye otnosheniya, 2009. P.567 - 573 (In Russian).

4. Vinogradova L. N., Tolstaya S. M. "Tot svet» ("Other world») // Slavyanskie drevnosti: Etnolingvisticheskii slovar' v 5-ti tomakh. Vol. 5. Moscow: Mezhdunarodnye otnosheniya, 2012. P.298 - 303 (In Russian). 
5. Zaliznyak A. A., Levontina I. B., Shmelev A. D. Konstanty i peremennye russkoi yazykovoi kartiny mira (Constants and Variables of the Russian Language Picture of the World). Moscow: Yazyki slavyanskikh kul'tur, 2012. 696 p. (In Russian).

6. Zelenin D.K. Izbrannye trudy. Stat'i po dukhovnoi kul'ture 1901-1913 (Selected Works. Articles on Spiritual Culture 1901-1913). Moscow: «Indrik», 1994. P.105 - 150 (In Russian).

7. Ivanov V. V., Toporov V. N. Baba Yaga // Slavyanskaya mifologiya: entsiklopedicheskii slovar'. 2-e izd. Moscow: Mezhdunarodnye otnosheniya, 2002. 512 p. (In Russian).

8. Laushkin K. D. Baba-Yaga i odnonogie bogi (K voprosu o proiskhozhdenii obraza) (Baba Yaga and One-Legged Gods (On the Question of the Origin of the Image)) // Fol'klor i etnografiya. Leningrad: Nauka, 1970. P.181-186. (In Russian).

9. Novichkova T. A. Russkii demonologicheskii slovar' (Russian Demonological Dictionary). St.Petersburg: Peterburgskii pisatel', 1995. 640 p. (In Russian).

10. Pierce Ch. S. Chto takoe znak? (What is a Sign?) // Vestnik Tomskogo gosudarstvennogo universiteta. Filosofiya Sotsiologiya. Politologiya. Tomsk: TSU publ., 2009. P.88-95 (In Russian).

11. Propp V. Ya. Istoricheskie korni volshebnoi skazki (The historical roots of the fairy tale). Moscow: Labirint, 2000. $274 \mathrm{p}$ (In Russian)

12. Sedakova I. A. Mel'nitsa (Mill) // Slavyanskie drevnosti: Etnolingvisticheskii slovar' $\vee 5$-ti tomakh. Vol. 3. Moscow: Mezhdunarodnye otnosheniya, 2004. P.222-225 (In Russian).

13. Stepanov Yu. S. Konstanty: Slovar' russkoi kul'tury (Constants: Dictionary of Russian Culture). Moscow: Yazyki russkoi kul'tury, 2004. 824 p. (In Russian).

14. Ternovskaya N. A., Tolstoi N. I. Baba (Woman) // Slavyanskie drevnosti: Etnolingvisticheskii slovar'v 5-ti tomakh. Vol. 1. Moscow: Mezhdunarodnye otnosheniya, 1995. P.122-123 (In Russian).

15. Tolstaya S. M. Smert' (Death) // Slavyanskie drevnosti: Etnolingvisticheskii slovar' v 5-ti tomakh. Vol. 5. Moscow: Mezhdunarodnye otnosheniya, 2012. P.58-71 (In Russian).

16. Curtin I. Myths and Folk-Tales op the Russians, Western Slavs and Magyars. London, 1890. 551 p.

Сведения об авторе

Писаренко Дарья Александровна - аспирант кафедры русского языка гуманитарного института Северо-Кавказского федерального университета (Ставрополь) / darja-pisarenko@rambler.ru

\section{Information about the author}

Pisarenko Daria - post-graduate student, Chair of Russian Languge, Institute for the Humanities, NorthCaucasus Federal University (Stavropol) / darja-pisarenko@rambler.ru 